In Press,

International Journal of Law, Crime and Justice

\title{
The Forensic Disclosure Model:
}

\section{What Should be Disclosed To, and By, Forensic Experts?}

\author{
Mohammed A. Almazrouei ${ }^{1,2}$, Itiel E. Dror ${ }^{1,2}$, and Ruth M. Morgan ${ }^{1,2}$ \\ ${ }^{1}$ UCL Security and Crime Science, University College London \\ ${ }^{2}$ UCL Centre for the Forensic Sciences, University College London
}

Corresponding author:

Itiel E. Dror (email address: i.dror@ucl.ac.uk) 


\begin{abstract}
Legal disclosure issues have predominantly focused upon what evidence the prosecution provided or withheld from the defence. In this paper we expand the concept of disclosure to wider contexts in which disclosure failures may result in miscarriages of justice. We introduce a conceptual model of 'forensic disclosure' which addresses what information should be disclosed to forensic examiners, as well as what information should be disclosed by forensic examiners. This paper presents a holistic overview of the dynamic interactions of four categories of stakeholders: forensic services, investigation, legal, and external stakeholders. We discuss the effective implementation of the forensic disclosure model by addressing five questions: when? what? how? who? and why? should information be best given to, and by, forensic examiners in order to increase the quality of forensic decision making and to minimise bias.
\end{abstract}

\title{
Highlights
}

- A new conceptual model of 'forensic disclosure' is presented.

- Forensic disclosure entails what should be disclosed 'to' and 'by' forensic examiners

- Forensic disclosure minimizes bias by making sure the examiners only receive taskrelevant information

- Forensic disclosure minimizes bias cascade and bias snowball effects by making sure that examiners do not convey irrelevant information, and only convey their findings to the appropriate stakeholders

Keywords: disclosure; forensic disclosure; cognitive bias; decision-making; forensic science; irrelevant contextual information. 


\section{The Forensic Disclosure Model: What Should be Disclosed To, and By, Forensic Experts?}

\section{Introduction}

Forensic science is a multidisciplinary field in which science, practice, law and policy come together to support the legal process (Morgan, 2017a). Testimony by forensic experts often carries significant weight in the criminal justice system as it is generally considered to offer impartial and scientifically based evidence (Dror et al., 2015). Whilst there have been criticisms directed at the validity of some forensic science techniques and methods (e.g., Saks and Koehler, 2005), there have also been a number of challenges and concerns reported regarding the communication of expert testimony and overstatements of expertise (Howes, 2015; Dror et al., 2015). Particularly important and relevant is the issue of bias in forensic decision making (Dror, 2016, 2018). A number of national bodies in the USA and UK (including the USA National Research Council (2009), the President's Council of Advisors on Science and Technology (PCAST, 2016), and the National Commission on Forensic Science (2015); and the UK Forensic Science Regulator (2015), the Fingerprint Inquiry (2011) and the House of Lords Inquiry (2019)), have all reported serious concerns with regard to bias in forensic expert decision making. It is important to note that this is cognitive and implicit bias which impacts hard working, dedicated, motivated and competent examiners in every field.

In the emerging domain of 'cognitive forensics' (Dror and Stoel, 2014; Found, 2015), a spectrum of factors that may affect forensic expert decision-making have been outlined (Mattijssen et al., 2016; Dror, 2017). A growing body of empirical research has demonstrated the existence of biases in forensic expert decision making across forensic domains, from crime scene examination (van den Eeden et al., 2016; de Gruijter et al., 2016; van den Eeden et al., 2018), to forensic anthropology (Nakhaeizadeh et al., 2014; Nakhaeizadeh et al., 2017), handwriting analysis (Kukucka and Kassin, 2014), and blood pattern analysis (Taylor et al., 2016a; Taylor et al., 2016b; Osborne et al., 2016); and from the comparatively less established forensic domains, such as bitemark analysis (Page et al., 2012; Osborne, et al., 2014) to the more established domains of fingerprints (Dror et al., 2006; Dror and Rosenthal, 2008; 
Earwaker et al., 2015; Smalarz et al., 2016; Stevenage and Bennett, 2017) and even DNA (Dror and Hampikian, 2011).

It is a misconception that cognitive bias is simply an ethical or competence issue, that can be overcome by better information, training or willpower (Dror, 2013). Cognitive biases are inherent to all decision making in every domain, as a result of how information is processed by the brain (Gigerenzer and Gaissmaier, 2011), and bias can, at a subconscious level, affect the inferences and interpretation of forensic science evidence (Morgan, 2017a). It is therefore possible for evidence to be misinterpreted, which can lead to miscarriages of justice (Smit et al., 2018), and erroneous identifications, such as the well-known example of Mayfield (Office of the Inspector General, 2006; see also the McKie case, Fingerprint Inquiry, 2011).

Legal disclosure predominantly refers to the legal duty of the prosecution to disclose to the defence materials that have been collected throughout the investigation process, even (and especially) if they are not used by the prosecution (e.g., in the UK, Her Majesty's Crown Prosecution Service Inspectorate and Her Majesty's Inspectorate of Constabulary, 2017). There have been an increasing number of cases where issues with legal disclosure have been identified that have had significant consequences for individual cases specifically, and for the justice system more generally, which have led to calls for reform (McCartney, 2018).

In this paper we seek to expand the legal concept of disclosure to the forensic science domain, and develop the concept of forensic disclosure. We argue that there is potentially value in carefully extending a principle of 'openness' to the whole forensic science process (crime scene to court) (Morgan, 2017a), whilst being mindful of each constituent part within that process, and their different requirements. This paper outlines the importance of 'forensic disclosure' and how a consideration of openness may be applied to the forensic science process to assist in providing transparency to how conclusions have been reached. In addition, the value of controlling the flow of information and evidential materials 'to' and 'by' forensic examiners, in order to identify and minimise the impact of potential factors that could affect the decisionmaking of experts is addressed. Taking this approach presents a pathway for ensuring that forensic examiners get all the information and evidence they need to conduct the forensic task at hand, but not more; and that forensic examiners disclose all the necessary information and evidence that is needed to demonstrate the scientific weight and significance of a conclusion, but only to the relevant stakeholders at the appropriate time. 
The importance of considering the role of judgement and decision making within the forensic science process has been demonstrated in a range of studies (Roux et al., 2012; Taylor et al., 2016a; Taylor et al., 2016b; Stevenage and Bennett, 2017; Nakhaeizadeh et al., 2017). Decision making is an inherent and intrinsic part of the forensic science process (Morgan et al., 2018), and yet it is arguably one of the least well defined and articulated parts in the delivery of a forensic reconstruction. It has been identified that decision making in forensic science is susceptible to extrinsic and intrinsic factors and that unconscious biases can occur in a wide range of different scenarios. Therefore, for minimally biased evaluations of forensic materials and for transparency to be achieved, 'forensic disclosure' needs to be considered. Forensic disclosure establishes what should be disclosed 'to' and 'by' forensic examiners. It is about making sure that forensic examiners get the necessary task-relevant information and forensic materials, and that examiners then provide the relevant information and materials to the appropriate people. In addition to information and forensic evidence management, forensic disclosure allows transparency of the context, interactions and pathways of decision making within the forensic science process, thereby disclosing how an inference was made, and within what context.

The forensic disclosure model we present here therefore addresses both what is disclosed to the forensic examiner prior to and during analysis being undertaken, and what the forensic examiner discloses formally in their report and court testimony, as well as in any informal discussions and interactions (e.g., discussions with other forensic examiners, lawyers, police officers, etc.). There are five questions that need addressing for effective implementation of the forensic disclosure model (which are illustrated with examples in Section 2): What information was given to and given by the forensic examiner? When? By/to whom? How? and Why?

\section{What Information Should be Disclosed to Forensic Experts?}

This section will focus on the first part of the forensic disclosure model; the information to be disclosed 'to' forensic examiners. Figure 1 illustrates the interactions and decision-making pathways of different domains within the forensic reconstruction process. Identifying and documenting the contextual information and possible cognitive biases which may arise from the interactions and decision making pathways that could affect the impartiality of forensic expert judgment and decision making, need to be laid out and understood so that limits are imposed upon what is disclosed to forensic scientists as task-relevant information. Therefore, 
an elementary understanding of pathways that affect expert decision-making is necessary in order to mitigate the influx of 'cognitive contaminating' information (Kassin et al., 2013) to forensic examiners and thereby achieve effective forensic disclosure. It is then possible to provide what is needed, when it is needed, and to the appropriate persons in a suitable manner.

During casework, forensic examiners can interact with individuals and institutions that can be categorised into four broad domains: A. forensic services, B. investigative, C. legal and D. external stakeholders (See Figure 1). The interactions between different domains are dynamic and complex (Howes 2015). The pathways of interactions can on some occasions be bidirectional (e.g., with investigators and lawyers, where information flows in both directions), and on other occasions uni-directional (e.g., a forensic examiner attending a crime scene could possibly be receiving information from the paramedics on the location and status of the body when the paramedics arrived at the scene before the arrival of the forensic examiner). The pathways of these interactions can occur at different levels within the same domain or across different domains (Figure 1).

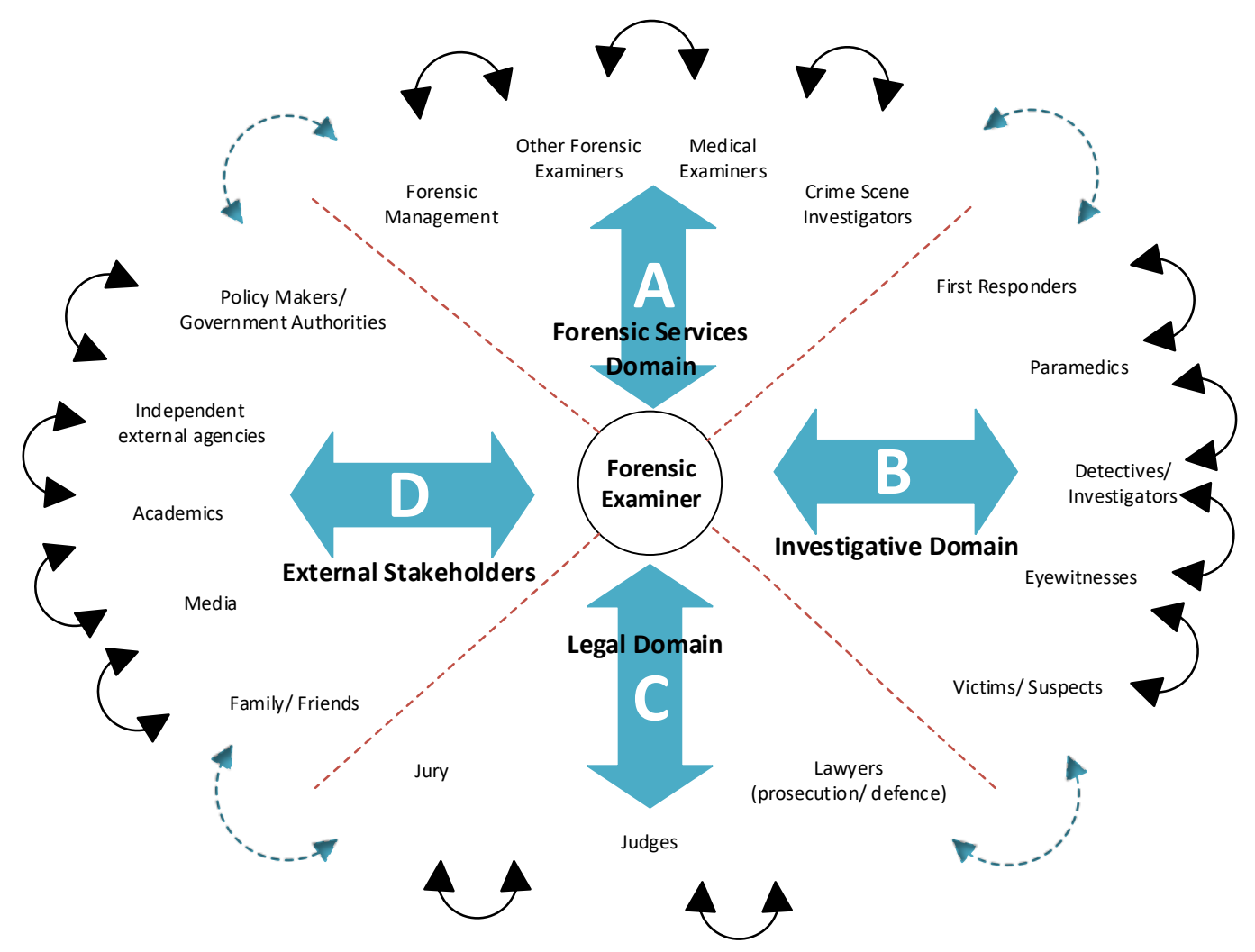

Figure 1: Interactions and decision-making pathways of different parties with the forensic examiners. Forensic science services (A); investigative domain (B); legal domain (C); external stakeholders (D); multiple pathways of interactions with the forensic examiners which could be uni-directional or bi-directional (thick, blue double arrows); within-domain interactions (black double arrows); cross-domain interactions (dotted blue double arrows). 
Figure 1 conveys the different pathways of interactions with the forensic experts (the 'who' question). In order to address the other four questions to be asked under the forensic disclosure model (i.e., 'what', 'when', 'how' and 'why' information is disclosed to and by the forensic experts) a consideration of the seven-factor taxonomy (Figure 2; Dror 2017, p. 543) is valuable, as it addresses the factors that may unconsciously affect the decision making of forensic experts, and their application to forensic reconstruction. The seven factors are considered within three categories. The first category is focused on case-specific information and includes factors such as the case evidence itself, reference materials and irrelevant case information. The second category focuses on the environment, culture and experience of forensic examiner and includes motivation, training, organisational factors and base rate expectations. The third category (human nature) includes fundamental forms of bias arising from the cognitive architecture of the brain (Figure 2). The factors that are important when considering what should be disclosed 'to' forensic examiners under the forensic disclosure model are: case evidence, reference materials, irrelevant case information, base rate expectations and organisational factors. To demonstrate the importance of considering these factors it is helpful to consider a number of hypothetical examples. These examples are not intended to be comprehensive; rather they are provided to illustrate the forensic disclosure model and its importance in minimising bias factors and increasing transparency within the forensic science process (from crime scene to court).

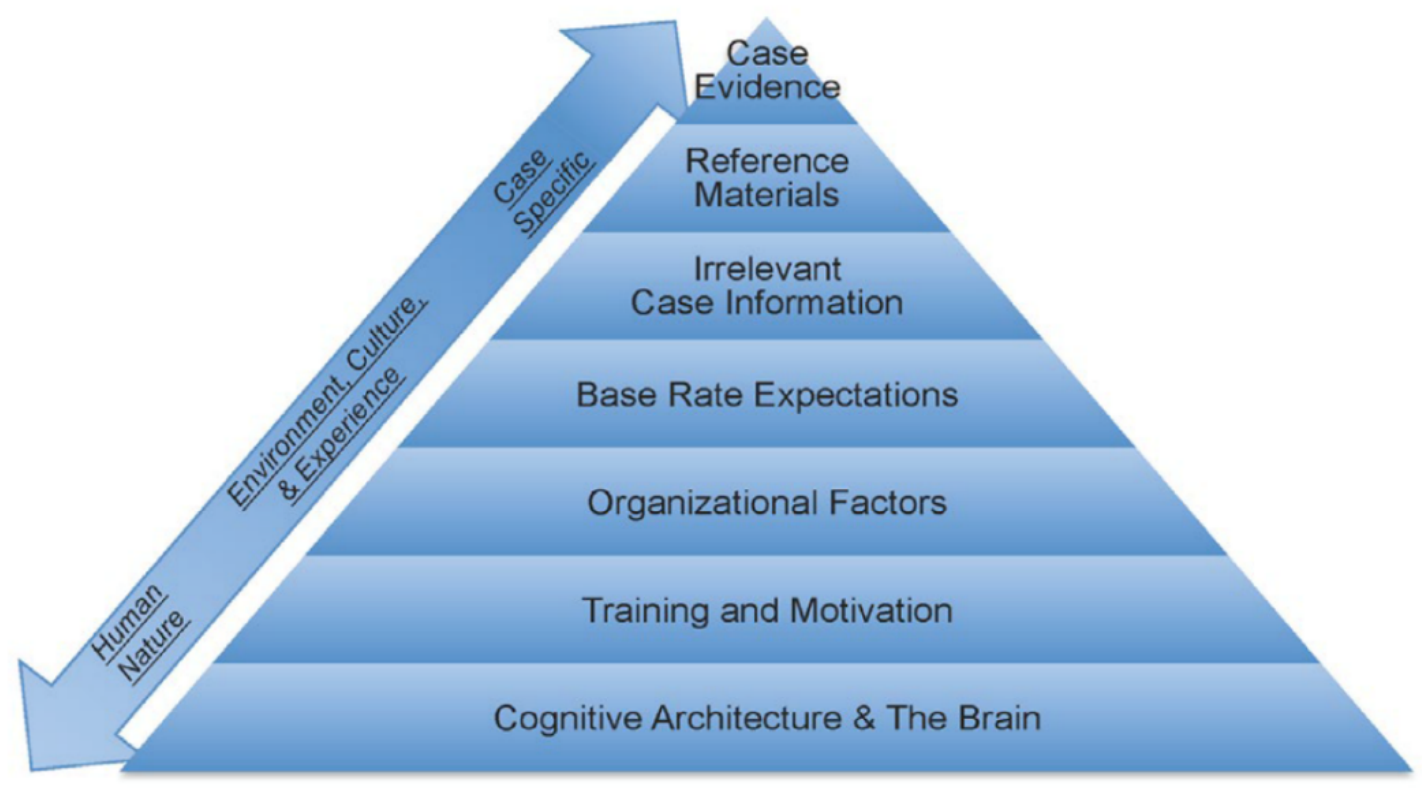

Figure 2: Taxonomy of seven factors that may unconsciously affect the decision making of forensic experts (Dror, 2017, p. 543). 
The case evidence (first factor within the case specific category) may convey taskirrelevant information that can bias expert decision-making, within the actual case evidence itself (Figure 2). For instance, a forensic odontologist examining a bite mark on a child reveals the nature of the crime and a variety of potential emotional and empathy biases (Page et al., 2012; Osborne, et al., 2014). The more complex and ambiguous the case evidence is, the nearer the decision is to the 'decision threshold', the more likely the judgement of forensic expert will be affected (Forensic Science Regulator, 2015; Dror and Langenburg, 2018). For example, interpretation of a DNA mixture of two donors is more difficult and requires subjective judgements in comparison to a single source DNA profile (Krane et al., 2008).

In relation to bias arising from the case evidence itself, Dror (2013) proposes removing taskirrelevant information that is potentially biasing from the evidence submitted to examiners. Hence, forensic disclosure may entail removing the task-irrelevant information from the case evidence, when possible, and not disclosing them to the examiner (the 'what' and 'how' questions of forensic disclosure). In the previous example, for instance, only the bite mark image should be submitted to the odontologist (Page et al., 2012; Osborne, et al., 2014). Table 1 provides further details on specific factors affecting subjective forensic expert decisionmaking and some proposed mitigation strategies. 
Table 1: Factors affecting forensic decision-making: Some examples and proposed approaches.

\begin{tabular}{|c|c|c|c|c|}
\hline Factor* & Some specific examples & References & Some proposed approaches & References \\
\hline \multirow[t]{2}{*}{ Case Evidence } & $\begin{array}{l}\text { Evidence itself may convey task-irrelevant information without } \\
\text { external factors. }\end{array}$ & $\begin{array}{l}\text { (Page et al., 2012; Dror, } \\
\text { 2013; Osborne, et al., 2014) }\end{array}$ & $\begin{array}{l}\text { Removal of potential task-irrelevant information from } \\
\text { evidence. }\end{array}$ & $\begin{array}{l}\text { (Page et al., 2012; } \\
\text { Dror, 2013; Osborne, } \\
\text { et al., 2014) }\end{array}$ \\
\hline & Difficulty and ambiguity of evidence differs. & \multirow{3}{*}{$\begin{array}{l}\text { (Krane et al., 2008; Forensic } \\
\text { Science Regulator, 2015; } \\
\text { Dror and Langenburg, 2018) } \\
\text { (Krane et al., 2008; } \\
\text { Kassin et al., 2013; Dror et } \\
\text { al., 2015; Stevenage and } \\
\text { Bennett, 2017) }\end{array}$} & $\begin{array}{l}\text { It is important to incorporate a consideration of individual } \\
\text { cases and the pertinent variables and certain context of each } \\
\text { case into the presentation of conclusions. }\end{array}$ & $\begin{array}{l}\text { (Morgan 2017a; } \\
\text { Morgan et al., 2018) }\end{array}$ \\
\hline \multirow[t]{2}{*}{$\begin{array}{l}\text { Reference } \\
\text { Materials }\end{array}$} & \multirow[t]{2}{*}{$\begin{array}{l}\text { An expert is provided with the suspect material before or while } \\
\text { they examine the evidence from the crime scene (working from } \\
\text { suspect to evidence rather than the other way around). }\end{array}$} & & \multirow{2}{*}{$\begin{array}{l}\text { Linear Sequential Unmasking (LSU) where reference material } \\
\text { is provided to examiners only after the crime evidence is fully } \\
\text { examined and documented, and changes made after exposure to } \\
\text { reference material are restricted and documented. } \\
\text { Evidence line up of a number of samples - the sample of } \\
\text { suspect and some plausible 'fillers'-is presented to an } \\
\text { examiner who does not know which is the target sample. }\end{array}$} & $\begin{array}{l}\text { (Krane et al., 2008; } \\
\text { Dror et al., 2015; } \\
\text { Koppl, 2018) }\end{array}$ \\
\hline & & & & $\begin{array}{l}\text { (Kassin et al., 2013; } \\
\text { Smalarz et al., 2016; } \\
\text { Stevenage and Bennett, } \\
\text { 2017) }\end{array}$ \\
\hline $\begin{array}{l}\text { Irrelevant Case } \\
\text { Information }\end{array}$ & $\begin{array}{l}\text { Contextual, task-irrelevant information, such as eyewitness } \\
\text { statements and case details, that a forensic expert is exposed to } \\
\text { when making decisions. }\end{array}$ & $\begin{array}{l}\text { (e.g., Dror et al., 2006; } \\
\text { Found and Ganas, 2013; van } \\
\text { den Eeden et al., 2016; } \\
\text { Osborne et al., 2016) }\end{array}$ & $\begin{array}{l}\text { Context (information) management tools, such as context } \\
\text { managers as a permanent or rotating role among examiners, so } \\
\text { that task-irrelevant information is filtered before reaching the } \\
\text { examiner who does the actual forensic work, and the } \\
\text { information flow is documented. }\end{array}$ & $\begin{array}{l}\text { (e.g., Saks et al., 2003; } \\
\text { Kassin et al., 2013; } \\
\text { Mattijssen et al., 2016; } \\
\text { Osborne and Taylor, } \\
\text { 2018) }\end{array}$ \\
\hline \multirow[t]{2}{*}{ Base Rate } & \multirow[t]{2}{*}{$\begin{array}{l}\text { Almost always verifications are made for positive identifications } \\
\text { (e.g., a fingermark match) so that over time the verifier could } \\
\text { develop cognitive expectations (a 'base-rate'). }\end{array}$} & \multirow[t]{2}{*}{$\begin{array}{l}\text { (Dror, 2013; Stevenage and } \\
\text { Bennett, 2017) }\end{array}$} & $\begin{array}{l}\text { Blind verification where the verifier does not know the } \\
\text { judgement and decision-making of the examiner in advance, } \\
\text { and where the verifier examines all decisions (not only positive } \\
\text { identifications). }\end{array}$ & $\begin{array}{l}\text { Koppl, 2005; Kassin } \\
\text { et al., 2013; Stevenage } \\
\text { and Bennett, 2017; } \\
\text { Osborne and Taylor, } \\
\text { 2018) }\end{array}$ \\
\hline & & & $\begin{array}{l}\text { Random counter-expectation cases/evidence are interjected } \\
\text { during the verification process (e.g., non-matching fingermarks } \\
\text { that look alike to be verified as identification) }\end{array}$ & $\begin{array}{l}\text { (Dror, 2013; Stevenage } \\
\text { and Bennett, 2017) }\end{array}$ \\
\hline $\begin{array}{l}\text { Organisational } \\
\text { factors }\end{array}$ & $\begin{array}{l}\text { Many forensic service providers operate within police organisations } \\
\text { where pressures, for example, to integrate } \\
\text { quality management procedures within their practices or to } \\
\text { complete forensic tasks faster are in place. }\end{array}$ & $\begin{array}{l}\text { (e.g., National } \quad \text { Research } \\
\text { Council, 2009; Raymond } \\
\text { and Julian, 2015; Stevenage } \\
\text { and Bennett, 2017) }\end{array}$ & $\begin{array}{l}\text { Forensic service provision as an independent activity to the } \\
\text { police (for example Houston Forensic Science Center and the } \\
\text { Scottish Police Authority), yet the communication channels } \\
\text { between the lab and police need to be effectively managed to } \\
\text { avoid the loss of vital information. }\end{array}$ & $\begin{array}{l}\text { (National Research } \\
\text { Council, 2009; Dror, } \\
\text { 2013) }\end{array}$ \\
\hline
\end{tabular}


The second factor within the case specific category can originate from the reference material used in an examination (Dror, 2017). For example, when a DNA or fingerprint expert is provided with the suspect DNA or fingerprint, before or while they examine and document the evidence from the crime scene, subconscious expectations of a relationship between the two may impact the interpretation of the evidence, so it better 'matches' the suspect (Jeanguenat et al. , 2017). This type of bias was observed in $R V$ Smith (2011) when the Court of Appeal of England and Wales quashed a murder conviction because the fingerprint expert changed his observations of a latent fingermark, after he was exposed to the fingerprint of the suspect. The examiner in this case initially concluded that the crime latent fingermark did not have sufficient features for comparison (before having a suspect fingerprint), but when the appellant was charged, the fingerprint examiner re-visited the evidence, made a new judgment that determined that the latent fingermark was sufficient for comparison and matched it to the left forefinger of suspect (See Figure 2 and Table 1).

In order to mitigate potential bias from the reference material, it has been suggested that the proper approach and best practice is to control the sequence and timing (the 'when' question) of reference material disclosure (Krane et al., 2008; Dror et al., 2015; Smalarz et al., 2016; Koppl, 2018). The reference material is relevant and essential, but by using Linear Sequential Unmasking (LSU) approach and revealing the reference material only after the crime evidence is fully examined and documented will reduce the bias effect of the reference material (Krane et al., 2008; Dror et al., 2015).

An evidence line-up (similar to an eyewitness line-up) is another practical mitigation strategy that has been proposed to remove potential bias from reference material (Kassin et al., 2013; Smalarz et al., 2016; Stevenage and Bennett, 2017) (Table 1). Hence, forensic disclosure (when considering reference material) does not involve removing task-irrelevant information from the evidence (as in the first factor of case evidence), but here taking a forensic disclosure approach involves either controlling the sequence in which information is disclosed (Dror et al., 2015) or disclosing the target information along with fillers (Kassin at al., 2013; Smalarz et al., 2016; Stevenage and Bennett, 2017).

The final factor within the 'case-specific category' is when task-irrelevant contextual information beyond the evidence is provided to the experts (Dror, 2017; Figure 2). For instance, Osborne et al. (2016) concluded that contextual information, such as medical findings on blood-letting injuries sustained by the victim or the suspect (e.g., autopsy findings that blunt 
force trauma to the head was the cause of death) have a biasing effect on judgments of bloodstain pattern analysts. Similarly, Dror et al. (2006) found that fingerprint experts can change their previous identification decisions so as to concur with new irrelevant biasing contextual information that had nothing to do with the forensic decision making.

One approach for controlling the task-irrelevant biasing information that a forensic expert is exposed to when making decisions could potentially be achieved by incorporating a context (information) manager into the forensic reconstruction process (Risinger et al., 2002; Saks et al., 2003; Kassin et al., 2013; Dror, 2013). A role of this nature controls who gets what information and when, and it has been successfully used to control contextual information in handwriting analysis (Found and Ganas, 2013), firearms examination (Mattijssen et al., 2016), and in bloodstain pattern analysis (Osborne and Taylor, 2018). There is a case to be made that 'gate keepers' (such as case managers) should be the main point of contact with access to the contextual information pertinent to a case so that they are able to remove what they determine as task-irrelevant information (e.g., Saks et al., 2003; Found and Ganas, 2013; Kassin et al., 2013; Mattijssen et al., 2016) (Table 1).

Case managers are in a position to document the entire process and the decisions that have been made at every stage (Saks et al., 2003). In doing so, the flow of information 'to' the forensic examiners (and 'by' forensic examiners as will be detailed in Section 3) is controlled and documented. Thus, it is possible to have a documented process to what information was and was not shared in a particular case, and this is to be disclosed under the forensic disclosure model. In addition, we suggest that context managers would assist prosecutors and investigators in understanding how the results from forensic analysis work relate to the case at hand. Even when unfiltered information is disclosed, this type of controlled and compartmentalised environment acts as a second barrier to shield examiners from taskirrelevant information, and allows for management and transparency in communicating information in the forensic reconstruction process. These 'gate keepers' should be in place within the forensic science organisations.

The types of factors included in the 'Environment, Culture and Experience' category (Figure 2), arise from more general influences (in comparison to the 'Case Specific' factors). One factor in this category is the base rate expectation that arises from previous experience and regularities from previous cases. Such experiences are vital for development of expertise, but also cause expectations that may be irrelevant and misleading in the current case (Dror, 2013; 
Stevenage and Bennett, 2017). For example, most forensic laboratories only verify positive identification results, and the vast majority of these are confirmed in the verification process.

To mitigate this, 'blind verification' can be utilised, where the verifications are made for all decisions (i.e., identifications, exclusions and inconclusive outcomes) and not only positive identifications are verified (Table 1). In addition, the verifier does not know the judgement of the examiner during blind verifications (Kassin et al., 2013; Stevenage and Bennett, 2017). In this way the verifier works in an environment as free as possible from 'cognitive contamination' and does not know what they are verifying in a given situation (e.g., Osborne and Taylor, 2018). This is critical to fight base rate bias, as when only positive identifications are verified, or if the verifier knows what decision they are verifying, these create a base rate expectation and bias in that the original identification decisions will be verified.

Another proposed approach to deal with base rate bias is to interject examples to counter the base rate regularity. For example, in the verification process to include similar non-matches (i.e., they look alike) to be verified as identifications (Dror, 2013; Stevenage and Bennett, 2017). For forensic disclosure purposes, the verification process should be well documented and be disclosed as a matter of normal practice. It needs to be clear whether the verifier was blind to the extraneous case details, decisions and notes of examiners before the verification, and whether the decisions or confidence levels on decisions made by verifier were different than that of the examiner (see also Table 2 for more details). All of the discussed matters relevant to the verification process should be disclosed routinely within the forensic disclosure model approach.

Another factor in the 'Environment, Culture and Experience' category is organisational factors (Figure 2). Whilst there is a lot of variation within different jurisdictions, there are many forensic service providers that operate within and as part of police organisations, and even within and as part of the prosecution such as The Santa Clara County District Attorney's Crime Laboratory (2018). Concerns have been raised about the degree to which this could introduce potential influences in expert decision making and pressures (National Research Council, 2009; Raymond and Julian, 2015). This, of course, raises issues of close relationships and inappropriate disclosures (McCartney, 2018), and calls for independence of forensic service providers from police organisations (National Research Council, 2009; see also Quirk (2006) for issues relating to working cultures and practices). This is an example of a disclosure issue, where information is (or is not) disclosed because of organisational factors. The issue is not 
only contingent upon which organisational framework the forensic examiners is situated in (e.g., police, commercial companies, or independent institutions (Morgan 2017b)), but if, and to what extent, the forensic examiners are able to approach their work as 'scientific endeavour' (Morgan 2017a) and given an independence of mind to do their work, with minimal expectations and pressures (Dror, 2009).

Hence, removing forensic work from the police by no means assures the absence of organisational factors which may potentially influence expert decision-making, especially that every organisation has its own culture and biases. What is important, regardless of where forensic examiners work, is to maximise their autonomy and independence of mind (Dror, 2009). A technique that can be adopted to mitigate inappropriate disclosures involves controlling, or at least fully documenting, the interactions between law enforcement and forensic scientists and thereby the flow of information (Figure 1). In this approach, direct contact between the investigating officers and the scientists doing the forensic work is not encouraged, for example, by utilising a centralised flow of information, which can be achieved through the role of a case manager that has already been discussed earlier (Saks et al., 2003; Found and Ganas, 2013; Mattijssen et al., 2016), or alternatively, at the very minimum, the documentation by the forensic examiner of any such interactions and what information was conveyed.

The range of disclosure issues documented here regarding what should be disclosed 'to' the forensic examiner is not intended to be comprehensive. However, it is clear that mechanisms that enable effective implementation of the forensic disclosure model on any identified factors that may affect expert decision-making are critical. Considering the complex, multi-layered, and dynamic interactions and pathways involved in expert decision-making through the five questions (when, what, how, who and why) offers a mechanism to achieve forensic disclosure. By way of demonstration, Table 2 outlines two examples of areas that may be analysed by considering the stage, context, pathway, interaction and presentation of evidence. This mechanism can be used for any potential information disclosed 'to' forensic examiner and also 'by' forensic examiner (Section 3). 
Table 2: Examples of the five questions to ask for effective disclosure using the forensic disclosure model

\begin{tabular}{|c|c|c|c|c|c|c|}
\hline $\begin{array}{l}\text { Forensic } \\
\text { decision- } \\
\text { making factor* } \\
\text { (Example) }\end{array}$ & References & $\begin{array}{l}\text { Stage } \\
\text { (When?) }\end{array}$ & $\begin{array}{l}\text { Context } \\
\text { (What?) }\end{array}$ & $\begin{array}{l}\text { Pathway } \\
\text { (How?) }\end{array}$ & $\begin{array}{l}\text { Interaction } \\
\text { (Who?) }\end{array}$ & $\begin{array}{l}\text { Presentation } \\
\text { (Why?) }\end{array}$ \\
\hline \multirow[t]{2}{*}{$\begin{array}{l}\text { Irrelevant Case } \\
\text { Information } \\
\text { (confessions) }\end{array}$} & $\begin{array}{l}\text { (e.g., Dror et } \\
\text { al., 2006; } \\
\text { Found and } \\
\text { Ganas, 2013; } \\
\text { van den Eeden } \\
\text { et al., 2016; } \\
\text { Osborne et al., } \\
\text { 2016) }\end{array}$ & $\begin{array}{l}\text { Was the forensic } \\
\text { expert informed } \\
\text { on the confessions } \\
\text { during crime } \\
\text { scene } \\
\text { examination, } \\
\text { forensic testing, or } \\
\text { court testimony? }\end{array}$ & $\begin{array}{l}\text { Which part of } \\
\text { the confession } \\
\text { statements did } \\
\text { the examiner } \\
\text { have (names, } \\
\text { full } \\
\text { confession, } \\
\text { etc)? }\end{array}$ & $\begin{array}{l}\text { Were the } \\
\text { confessions } \\
\text { information } \\
\text { provided } \\
\text { verbally or in } \\
\text { writing? }\end{array}$ & $\begin{array}{l}\text { Who provided } \\
\text { the details of } \\
\text { confessions? }\end{array}$ & $\begin{array}{l}\text { What was the } \\
\text { reason for } \\
\text { providing } \\
\text { confession details } \\
\text { to examiner? Was } \\
\text { it task-relevant? }\end{array}$ \\
\hline & & $\begin{array}{l}\text { Were the } \\
\text { confessions } \\
\text { provided before or } \\
\text { after the examiner } \\
\text { formulated their } \\
\text { conclusions? }\end{array}$ & & & $\begin{array}{l}\text { Was it the } \\
\text { context manager } \\
\text { (or a role of this } \\
\text { nature) or was it } \\
\text { an investigator? }\end{array}$ & $\begin{array}{l}\text { Was the scientific } \\
\text { significance of the } \\
\text { presented } \\
\text { evidence } \\
\text { formulated } \\
\text { entirely or } \\
\text { partially as a } \\
\text { result of the } \\
\text { confessions? }\end{array}$ \\
\hline \multirow[t]{2}{*}{$\begin{array}{l}\text { Base Rate } \\
\text { (verification } \\
\text { typically of } \\
\text { positive } \\
\text { identifications) }\end{array}$} & $\begin{array}{l}\text { (Dror, 2013; } \\
\text { Stevenage and } \\
\text { Bennett, 2017) }\end{array}$ & $\begin{array}{l}\text { Was the } \\
\text { verification made } \\
\text { at the } \\
\text { interpretation } \\
\text { stage of forensic } \\
\text { analysis? }\end{array}$ & $\begin{array}{l}\text { Were the notes } \\
\text { of first } \\
\text { examiner } \\
\text { given to } \\
\text { verifier? }\end{array}$ & $\begin{array}{l}\text { Did the } \\
\text { verifier know } \\
\text { the decisions } \\
\text { made by the } \\
\text { examiner? }\end{array}$ & $\begin{array}{l}\text { Does the verifier } \\
\text { typically verify } \\
\text { the work of the } \\
\text { same examiner } \\
\text { or the verifier is } \\
\text { chosen } \\
\text { randomly? }\end{array}$ & $\begin{array}{l}\text { Were the } \\
\text { decisions or } \\
\text { confidence levels } \\
\text { on decisions made } \\
\text { by verifier } \\
\text { different than that } \\
\text { of the examiner? }\end{array}$ \\
\hline & & $\begin{array}{l}\text { Were the } \\
\text { examination notes } \\
\text { given to verifier } \\
\text { before or after the } \\
\text { verification } \\
\text { completed? }\end{array}$ & $\begin{array}{l}\text { Did the } \\
\text { verifier know } \\
\text { the extraneous } \\
\text { case details? }\end{array}$ & $\begin{array}{l}\text { Was the } \\
\text { chosen } \\
\text { verification } \\
\text { process (e.g., } \\
\text { non-blind, } \\
\text { blind, double- } \\
\text { blind) } \\
\text { validated? }\end{array}$ & $\begin{array}{l}\text { Did the verifier } \\
\text { discuss the } \\
\text { evidence/ case } \\
\text { with examiner or } \\
\text { others? }\end{array}$ & \\
\hline
\end{tabular}

* Source: (Dror, 2017)

Hence, the forensic disclosure model, as it pertains to what needs to be disclosed 'to' the forensic examiner, is also about ensuring that biasing task-irrelevant extraneous information is not disclosed (National Commission on Forensic Science, 2015; Dror et al., 2018a). Indeed, Dror et al. (2018a) suggest that even when information is task-relevant and needs to be provided to forensic examiners, it should be given in a controlled documented manner, using context management tools, such as LSU, that minimise the risk of bias, and increase the transparency of the factors that may have influenced the conclusion reached. If such mechanisms to control disclosure have not taken place, the court should evaluate the impact of the disclosure on the expert testimony (Dror et al. 2015). Also, when appropriate, and as with eyewitness testimony, direct instructions to the jury should be provided to outline potential cognitive biases in forensic expert testimony. 


\section{What Information Should be Disclosed by Forensic Experts?}

As outlined in Section 1, there are two elements in the forensic disclosure model. The first is the information disclosed 'to' the forensic examiner and how it impacts their observations, interpretations and the conclusions they reach. The second is what is disclosed 'by' the forensic examiner. In order to assess the value of 'forensic disclosure' and what information should be disclosed by forensic experts, it is valuable to consider the current legal disclosure guidance that is relevant to forensic experts.

In the UK, for example, expert witnesses, including forensic experts, are provided with clear practical guidance, based on the Criminal Procedure and Investigations Act (CPIA) 1996, including the Code of Practice and Attorney General's Guidelines (Association of Chief Police Officers (ACPO) and Crown Prosecution Service (CPS), 2010). The CPIA clarifies the responsibilities of forensic experts in relation to the disclosure process. Forensic experts are obliged to "retain, record and reveal" (ACPO and CPS, 2010, p. 5) all unused material, such as contemporaneous notes and e-mails exchanged with/ by forensic experts, to the prosecution team, whose responsibility it is to decide what can be legally disclosed to the defence. The guidelines, however, do not consider disclosure of observations or conclusions of experts in light of cognitive issues affecting expert decision-making (Dror, 2016). Of course, merely stipulating disclosure may not achieve the desired result and we need to study how to structure disclosure requirements.

The forensic disclosure model extends the scope of what forensic experts should disclose to include:

i. having transparency in communicating the scientific significance of evidence;

ii. identifying disclosure issues that arise during casework;

iii. articulating whether expert decision-making is considered within the standard operating procedures; and

iv. when possible, providing the actual evidence for other experts to scrutinise.

\subsection{Transparency in communicating the scientific significance of evidence}

The first aspect regarding what forensic examiners should disclose is the transparency of communicating the evidential value of forensic science evidence. It has been well documented 
that communication within the whole domain of forensic science (from crime scene to court) and across all the stakeholders is critical (Howes, 2015). This is highly complex given the different types of knowledge that are generated within different institutions (Figure 1), and the explicit and tacit forms that knowledge takes (Morgan, 2017b; Kelty et al., 2018). There are many examples where forensic science evidence has been identified as being misleading (LaPorte, 2018), often due to the evaluative interpretation and conclusions reached not being communicated effectively by scientists, or the triers of fact.

In an examination of successful appeal cases at the Court of Appeal in England and Wales between 2010 and 2016, Smit et al. (2018) identified for the first time the extent of misleading evidence in the UK, with 235 cases that were upheld by the Court of Appeal which had misleading 'criminal evidence' (which included forensic science evidence) in the original trial (Similar findings were reported in the United States; e.g., Garrett, 2011). The findings of Smit et al. (2018) indicated that the relevance, probative value, and validity of evidence are often misunderstood or miscommunicated when expressing beliefs in (competing) hypotheses, and that this has led to wrongful convictions. One of the conclusions from these studies was that many of these misleading instances could have been prevented by providing more transparency. If there is no clear and explicit communication of the uncertainties, weaknesses and limitations of evidence then unsafe rulings are more likely to occur (Garrett, 2011; Smit et al., 2018).

A significant impact on the provision of appropriate disclosure has been the unwillingness to accept that forensic science experts are susceptible to biases - referred to as a "bias blind spot" (Pronin and Kugler, 2007). There have been a minority of null findings studies of cognitive bias (e.g., Kerstholt et al., 2006; Kerstholt, et al., 2010) and there have even been calls to avoid the use of context information management tools on the basis that extraneous information can improve consensus among experts (e.g., Oliver, 2018). However, the studies that demonstrate conditions where experts are impacted by context and biases have been substantial, and now extensively replicated, both in the forensic science domain (e.g., Page et al., 2012; Kukucka and Kassin, 2014; Smalarz et al., 2016; Stevenage and Bennett, 2017; van den Eeden et al., 2018, and many more -for a review, see Cooper and Meterko, 2019), as well as in other domains, such as medicine and finance (e.g., Corredor et al., 2014; Hussain and Oestreicher, 2018). 
The bias blind spot has been specifically demonstrated in forensic science (Kukucka et al., 2017) as well as in forensic psychology (Zapf et al., 2018). Open and transparent discussion of this issue among forensic practitioners, researchers and policy makers is needed if practical bias mitigations strategies are to be effectively implemented and if an approach that enables greater transparency in the communication of forensic evidence is to be achieved (Thompson et al., 2011; Morgan, 2017a). 
Table 3: A range of examples under the forensic disclosure model: what should be disclosed 'by' forensic experts?

\begin{tabular}{|c|c|c|c|}
\hline Main Disclosure Area & Factors to consider & References & What should be disclosed 'by' forensic experts? \\
\hline $\begin{array}{l}\text { Transparency in } \\
\text { communicating the } \\
\text { scientific significance of } \\
\text { evidence }\end{array}$ & $\begin{array}{l}\text { Relevance, probative value, and validity of evidence are often } \\
\text { misunderstood or miscommunicated when expressing beliefs in } \\
\text { (competing) hypotheses, and that this can lead to wrongful } \\
\text { convictions. }\end{array}$ & $\begin{array}{l}\text { (Howes, 2015; Smit et al., 2018; } \\
\text { LaPorte, 2018; Kelty et al., 2018) }\end{array}$ & $\begin{array}{l}\text { - Framework(s)/methods used to communicate the scientific weight of evidence } \\
\text { should be disclosed, in addition to whether such frameworks are empirically } \\
\text { tested and evidence-based. }\end{array}$ \\
\hline \multirow[t]{3}{*}{$\begin{array}{l}\text { Issues that arise during } \\
\text { casework }\end{array}$} & $\begin{array}{l}\text { All the identified contextual information that may have had an } \\
\text { impact on the decision making and conclusions reached. }\end{array}$ & $\begin{array}{l}\text { (e.g., Dror et al., 2006; ACPO and } \\
\text { CPS, 2010; Found and Ganas, } \\
\text { 2013; van den Eeden et al., 2016). }\end{array}$ & $\begin{array}{l}\text { - A disclosure through an evaluation report detailing identified potential } \\
\text { contextual information, the potential impact on expert judgment, and whether } \\
\text { any subjective decision-making countermeasures were taken after exposure. }\end{array}$ \\
\hline & $\begin{array}{l}\text { Organisational factors inevitably arise during case work, such } \\
\text { as workplace stresses of exposure to bloody scenes, and 'role } \\
\text { effect' bias, in the adversarial legal system, as the examiner is } \\
\text { retained by either the prosecution or the defence. }\end{array}$ & $\begin{array}{l}\text { (National Research Council, } \\
\text { 2009; Raymond and Julian, } \\
\text { 2015; Kelty and Gordon, 2015; } \\
\text { Dror, 2017; Jeanguenat and } \\
\text { Dror, 2018). }\end{array}$ & $\begin{array}{l}\text { - Forensic experts should document and disclose of any stresses or pressures they } \\
\text { encountered during casework and evaluate their impact on their judgment. } \\
\text { The instructions given to the experts by the legal side that retains them ought } \\
\text { to be disclosed, as well as the background and general briefing information that } \\
\text { was provided, and any other preparation and guidance that was provided to the } \\
\text { expert }\end{array}$ \\
\hline & $\begin{array}{l}\text { Documentation and management of forensic science } \\
\text { observations and conclusions, such as in cases of disputed } \\
\text { decisions or reporting of inconclusive findings. }\end{array}$ & $\begin{array}{l}\text { (Dror et al., 2015; Dror and } \\
\text { Langenburg, 2018). }\end{array}$ & $\begin{array}{l}\text { - Any changes to the decision-making outcome or the confidence level thereof } \\
\text { after exposure to reference material or other contextual information should be } \\
\text { documented and disclosed. } \\
\text { - A statement should be included in the final expert witness report that details } \\
\text { the details of any dispute. } \\
\text { - Forensic examiners need to clearly and transparently document, justify and } \\
\text { communicate inconclusive decisions. }\end{array}$ \\
\hline \multirow[t]{4}{*}{$\begin{array}{l}\text { Standard } \quad \text { operating } \\
\text { procedures (SoPs) }\end{array}$} & $\begin{array}{l}\text { Factors and countermeasures of expert subjective decision- } \\
\text { making, and limitations and error rates of methods, are not } \\
\text { currently incorporated within the SoPs. }\end{array}$ & $\begin{array}{l}\text { (e.g., Mattijssen et al., 2016; } \\
\text { Osborne and Taylor, 2018). }\end{array}$ & $\begin{array}{l}\text { - Standard operating procedures should be disclosed as a matter of routine } \\
\text { (unless there are justifiable commercial or legal reasons to not disclose the } \\
\text { procedures) to demonstrate whether human factors are considered or not, as } \\
\text { well as whether procedures have been followed. } \\
\text { - Weaknesses, limitations, error rates and potential bias within methods used } \\
\text { should be disclosed. }\end{array}$ \\
\hline & $\begin{array}{l}\text { The peer-review procedure may not be 'blind' or the review is } \\
\text { typically made by senior experts, whose opinions may overrule } \\
\text { those of the examiner. }\end{array}$ & $\begin{array}{l}\text { (e.g., Kassin et al., 2013; } \\
\text { Stevenage and Bennett, 2017; } \\
\text { Osborne and Taylor, 2018). }\end{array}$ & $\begin{array}{l}\text { The peer-review process should be available for disclosure, including whether } \\
\text { it was blind or not and any changes made to drafts and the rationale for such } \\
\text { changes. }\end{array}$ \\
\hline & $\begin{array}{l}\text { Organisational procedures may allow the same examiner(s) to } \\
\text { attend a crime scene and conduct a forensic examination, } \\
\text { resulting in "bias cascade effect" where bias introduced at early } \\
\text { stages of the forensic reconstruction process can impact } \\
\text { decisions made at a later stage. }\end{array}$ & $\begin{array}{l}\text { (Nakhaeizadeh et al., 2017; Dror } \\
\text { et al., 2017). }\end{array}$ & $\begin{array}{l}\text { - Roles and responsibilities of personnel involved at each stage of the forensic } \\
\text { reconstruction process (crime scene to court), and mitigation strategies, if any, } \\
\text { to cascading effects should be disclosed. }\end{array}$ \\
\hline & $\begin{array}{l}\text { Operating procedures do not restrict communication on cases } \\
\text { (e.g. among forensic examiners), so a "bias snowball effect" } \\
\text { may occur as one line of evidence/investigation influences and } \\
\text { cross-contaminates another. }\end{array}$ & $\begin{array}{l}\text { (e.g., Stevenage and Bennett, } \\
\text { 2017; Dror et al., 2017). }\end{array}$ & $\begin{array}{l}\text { Efforts (or lack thereof) made in order to mitigate snowball effects, such as } \\
\text { written guidance/ restrictions within the procedures on inter-disciplinary } \\
\text { forensic expert communications on shared casework, should be disclosed. }\end{array}$ \\
\hline The evidence itself & $\begin{array}{l}\text { On a practical level, can the actual evidence materials be } \\
\text { disclosed to other forensic science experts involved in the case? }\end{array}$ & - & $\begin{array}{l}\text { - If and when possible, the actual evidence materials should be provided and } \\
\text { disclosed, so other experts can directly conduct their own examination. This } \\
\text { should be done routinely without the need to have it subpoena via the court, or } \\
\text { require the approval of the lawyers - scientists should share the evidence (when } \\
\text { the type of evidence allows this) with other experts. }\end{array}$ \\
\hline
\end{tabular}

Page 18 of 34 
Ensuring transparency in the communication of the evaluative interpretation of evidence is not simple. This is due to every case being different, the role of each form of forensic evidence being contingent on the nature of the specific case, and the questions that are being addressed in that case (Howes, 2015; Morgan, 2017a,). For instance, in one case the source of a DNA profile may be highly significant (in the case of an assault by an unknown assailant), however, if the same crime has occurred but the assailant is known to the complainant, source level inferences will be of very limited value, as activity level inferences are required for a forensic reconstruction (Morgan 2017a). However, for effective forensic disclosure from the expert to the investigator or court, there is a need to develop transparent, evidence-based and reproducible frameworks of communicating the scientific significance of evidence to ensure that the scientific weight of evidence is appropriately and effectively communicated for the fact finder to sufficiently understand the evaluative interpretation of the evidence (Arscott et al., 2017; Berger and Stoel, 2018; Edmond et al., 2016; French et al., 2018). Therefore, under the forensic disclosure model, framework(s) and methods used to communicate the scientific weight of evidence should be disclosed, in addition to whether such frameworks are evidencebased and reproducible (Table 3). Additionally, in order for such empirically developed frameworks to be effectively implemented, there is a need for culture (Morgan, 2018) and policy changes such as when the disclosure regime was addressed in the latest CPIA (1996) changes in the UK (McCartney, 2018).

\subsection{Identifying disclosure issues that arise during casework}

In addition to the transparency of communicating the scientific weight of forensic evidence, the forensic disclosure model puts forward that examiners should disclose any issues that arose during their work (Table 3). The factors that are relevant to what should be disclosed 'by' forensic examiners include:
a) contextual information,
b) organisational factors,
c) documentation of expert decision-making process,
d) any disputes, disagreements and consultations, and
e) the communication of inconclusive decisions. 
All contextual information that can be identified should be disclosed so that it is possible to have a review (if needed at some point later) to identify extraneous material which may have had an impact on the decision making and conclusions reached (e.g., Dror et al., 2006; ACPO and CPS, 2010; Found and Ganas, 2013; van den Eeden et al., 2016). In instances where taskirrelevant information reached the forensic examiner, even with jurisdictions that implement 'gate keeping' systems such as context information management (discussed in Section 2), the exposure of unfiltered information and the potential effect on expert decision-making in that instance should be disclosed. An integral part of the forensic report needs to detail potential contextual information that reached the examiners, the stage(s) it reached the forensic expert (e.g., during crime scene examination or interpretation stage), the details of the extraneous information, and whether any bias countermeasures were taken. For consistency and effectiveness of disclosure, we suggest to utilise the five-question mechanism (what, when, who, how and why) discussed in Section 2, when deciding what forensic examiners should disclose in their expert witness reports.

Organisational factors inevitably arise during casework (National Research Council, 2009; Raymond and Julian, 2015; Morgan 2017b). Forensic examiners may encounter workplace stresses that affect their judgment and these should also be subject to forensic disclosure. For instance, an examiner might be affected by attendance at a particularly disturbing crime scene (Jeanguenat and Dror, 2018), or might have been experiencing a health problem during a case examination that could have impaired their judgment or other personal factors such as stress and fatigue from a forensic workload (Kelty and Gordon, 2015). Another organisational factor, especially in the adversarial legal system, is 'role effect' bias resulting from whether the forensic examiner is retained by the prosecution or the defence (Murrie et al., 2013; Forensic Science Regulator, 2015). In this respect, some researchers argue that a jointly-appointed expert who transparently communicates the legal matters of the same case with both the prosecution and the defence may reduce the role effect bias (Dror et al., 2018b), but even if this proposed solution was implemented, the forensic disclosure model mandates that the instructions given to the expert are disclosed, as well as the background and general briefing information that was provided, and any other preparation and guidance that was provided.

Another potential disclosure issue that may arise during casework relates to appropriate documentation and management of forensic observations and conclusions. For instance, in the application of LSU, any changes after exposure to reference material or other contextual information should be documented and disclosed to provide transparency in the decision- 
making process (Dror et al., 2015). Additionally, forensic reports should also disclose whether the decision was disputed during the analysis (Montani et al., 2019). Under the forensic disclosure model, a statement should be included in the final expert witness report that details the dynamics of the dispute, including the original and reported decision(s), whether there were confidence levels associated with the decision(s), the reasons behind the conflict of opinions and how the dispute was resolved.

Management and transparent communication of forensic conclusions, in particular 'inconclusive' decisions, is an important consideration. It has been observed that forensic examiners may make inconclusive decisions because it purportedly avoids reaching a definitive conclusion, and hence most often goes unchallenged (Dror and Langenburg, 2018). Such decisions may have an impact on the reported forensic conclusions; for example, it was found that fingerprint examiners, who were operating with a 16-point threshold of similarity to report an identification, tended to avoid reporting a borderline similarity of 15-points (Evett and Williams, 1996). One way to help overcome the unchallenged inconclusive decisions can be through forensic disclosure. As with identification and exclusion decisions, forensic examiners need to clearly and transparently document, justify and communicate inconclusive decisions (Dror and Langenburg, 2018).

\subsection{Articulating whether expert decision-making is considered in the standard operating procedures}

The third main aspect regarding what forensic examiners should disclose under the forensic disclosure model (in addition to the communication of value of evidence and issues that arise during casework) is that the standard operating procedures (SoPs) of the forensic lab need to be disclosed, unless there are justifiable commercial or legal reasons to not disclose the procedures (Table 3). This is particularly important if factors and countermeasures of expert bias have not yet been addressed within the SoPs. When human factors that might affect expert decision-making are not taken into account in the procedures, this should be evident in the disclosed procedures. For instance, during the case assessment stage prior to the examination, the expert formulating the strategy could have been exposed to task-irrelevant information; if they do not act as a context manager (i.e., context information management is not incorporated within the procedures) then the examiner will also receive the contextual information. 
Other disclosure issues relevant to operating procedures include the peer-review process and limitations of the methodology. During peer-review (e.g., Kassin et al., 2013; Stevenage and Bennett, 2017; Osborne and Taylor, 2018), the reviewer may suggest changes to the observations and/or conclusions of the original examiner such that the final report assigns different scientific significance to the evidence in comparison to the initial draft report. Any changes to drafts and the rationale for such changes should be documented and be disclosed as a matter of routine to offer transparency. Similarly, any weaknesses, limitations, error rates and susceptibility to bias within the procedural methods, which always exist in any scientific endeavour (National Research Council, 2009), should be explicitly identified in the reports and testimony.

Organisational procedures may, in some instances, allow the same examiner(s) to attend a crime scene and conduct a forensic examination. This can result in the "bias cascade effect", where bias flows from one stage of an investigation to another (Dror et al., 2017). For example, Nakhaeizadeh et al. (2017) demonstrated that exposure to information at the crime scene had a significant effect on subsequent sex assessments of skeletal remains at the laboratory. Dror et al. (2017) argue that the bias cascade effect can be countered by a degree of 'compartmentalisation' of the process. This can be achieved by involving different people in the forensic process at various stages. For example, individuals collecting the evidence at the crime scene should not be the same as those who analyse the evidence in the laboratory. Hence, under forensic disclosure, roles and responsibilities of personnel involved at each stage of the forensic science reconstruction process (crime scene to court) should be disclosed. This transparency enables the legal team to ascertain whether mitigation strategies were implemented to counter potential bias cascading factors, and evaluate the conclusions reached with a full picture of the relevant contextual factors.

On the other hand, when operating procedures do not restrict communication on cases, a "bias snowball effect" (Dror et al., 2017) can occur as one line of evidence/investigation influences and cross-contaminates another. The role of the forensic examiner is not to integrate different lines of evidence; this is the role of the investigators, lawyers, jurors, judges, etc. Forensic examiners need to focus solely on their area of expertise. The bias snowball effect highlights the far-reaching impact of disclosure. For example, disclosure of DNA results can inappropriately impact the analysis of fingerprints (Stevenage and Bennett, 2017). This causes "double-counting" of the evidence, since the DNA evidence is presented twice - implicitly in the fingerprint expert testimony and explicitly through the DNA expert testimony. If double 
counting is not disclosed, the evidence would inevitably mislead the fact finders (Dror et al., 2015). To avoid the snowball effect, it has been recommended that each forensic expert should remain within his/her area of expertise and not integrate it with other evidence (Forensic Science Regulator, 2015; Stevenage and Bennett, 2017; Dror et al., 2017). This is a clear issue where forensic disclosure of information can assist. Efforts (or lack thereof) made in order to mitigate snowball effects, such as written guidance/ restrictions within the procedures on interdisciplinary forensic expert communications on shared casework, should also be disclosed

There are therefore important aspects that forensic examiners should disclose. In contrast, there are also aspects that forensic examiners should not disclose. These include examiners not disclosing their findings to entities that are not pertinent to the reconstruction process (the 'who' question). Forensic examiners interact professionally and personally with other stakeholders (with other forensic examiners, police, etc.), and to avoid the cascade and snowball of bias (Dror et al., 2017), it is important to have and uphold procedures for only disclosing findings to the appropriate fact finders. In addition, forensic examiners should develop consciousness on the dynamics of interactions with stakeholders, particularly given that it has been reported that examiners may seek "personal satisfaction" by discussing case details as forensic science jobs can become tedious and routine (Butt, 2013, p. 60). Hence, forensic disclosure is not only about what, when and to whom information should be disclosed to and by, but also the limit of disclosure and the avoidance of sharing certain information that can impact the decision making of other stakeholders.

\subsection{Providing the actual evidence material for other experts to scrutinise}

When possible, forensic experts should share the actual evidence material with other experts, even and especially, with the experts retained by the opposing legal side. This should be done as a matter of routine, without requiring a subpoena from the court or approval by the lawyers. Scientists should share the evidence materials and findings so other scientists can run their own tests, make their own observations, interpretations, conclusions and forensic reconstruction in order that the court can be equipped with a full picture of the forensic science evidence and what it means in a specific case. Sometimes this is not technically and pragmatically possible (e.g., when a test destroys the evidence), but there are instances when there are no practical reasons to preclude sharing the evidence. Especially in the adversarial legal system, the concept of 'sharing' is currently minimal; often there is no willingness among the legal sides to share 
forensic science evidence findings, forensic evidence materials, or to 'share' a common forensic expert (Dror et al., 2018b)

According to the forensic disclosure model, scientific evidence should be routinely shared by both the prosecution and the defence regardless of the side retaining the forensic expert(s), or who they work for. Not only does the adversarial legal system make such a 'sharing' difficult, but economic interests can often pose issues around sharing knowledge (especially in a commercial market environment where such knowledge can have commercial value). The forensic disclosure model that we put forward in this paper is underpinned by the assertion that science and fair justice mandates that there is an openness and sharing of scientific findings, and even the scientific evidence materials. Forensic disclosure calls for transparency and maximum disclosure of the science, so science can be used (rather than abused or misused) in the administration of justice within the legal system.

Whilst there are legal and commercial obstacles that can hinder the effective implementation of this element of the forensic disclosure model, the fair administration of justice is paramount. Therefore, transparent and open discussions, particularly between the legal and forensic science domains, on the concept of routinely sharing the scientific evidence among both sides of the adversarial legal system are necessary looking forward. Policy changes can enable change, such as when the disclosure practice in the UK were revised (McCartney, 2018), but there is still some way to go to achieve the transparency and disclosure that is necessary.

This paper has introduced the model of forensic disclosure, which extends the limited scope of legal disclosure. Future work is needed to develop different approaches to implement and empirically test the model in different case scenarios. Merely stipulating that disclosure is needed may not achieve the desired result, therefore, there is a need to develop frameworks, which are beyond the scope of this paper, that outline a clear structure to achieve reproducible, transparent and effective two-way forensic disclosure ('to' and 'by' forensic examiners). For this to occur, all stakeholders from the forensic science, legal, investigative, and external stakeholder domains need to be involved in continuous and open discussions.

\section{Conclusion}

Disclosure, in the existing limited legal sense, of what information one party provides to the other, is about providing transparency and ensuring that all relevant materials are available to 
both prosecution and defence. The 'forensic disclosure' model expands the concept of disclosure and relates it to both what should be disclosed to the forensic examiner, and what the forensic examiner should disclose to others.

This paper sets out that information that is extraneous and task-irrelevant should not be disclosed to the forensic experts so as to reduce the degree to which that information and context may influence their decision making. Conversely, forensic experts need to share evidence materials, offer transparency and disclose all factors that they have been exposed to during the course of a forensic reconstruction, to ensure that their conclusions can be appropriately evaluated. At the same time, to avoid the cascade and snowball effects of bias, forensic examiners need to restrict disclosure of case information and findings only to the appropriate individuals within the reconstruction process. These are of course not simple tasks and achieving forensic disclosure therefore requires careful consideration of how to implement this approach within specific institutions and cases.

The forensic disclosure model thus presents a conceptual approach to control and regulate what information is given to, and given by, the forensic examiner, and also provide transparency that provides the means to re-examine how evidence was evaluated and what factors may have influenced the decision-making process. The next step is to develop clear structural requirements on how to implement the forensic disclosure model in practice in a manner that is possible to document and that is reproducible yet sensitive to the context of an individual case.

\section{Funding}

This research did not receive any specific grant from funding agencies in the public, commercial, or not-for-profit. 


\section{References}

Association of Chief Police Officers (ACPO), Crown Prosecution Service (CPS), 2010. Guidance booklet for experts. Disclosure: Experts' evidence, case management and unused material. Retrieved from https://www.cps.gov.uk/legal-guidance/disclosureexperts-evidence-case-management-and-unused-material-may-2010-guidance

Berger, C. E. H., Stoel, R. D., 2018. Response to "A study of the perception of verbal expressions of the strength of evidence" [Letter to the editor]. Science \& Justice, 58(1), $76-77$.

Butt, L., 2013. The forensic confirmation bias: Problems, perspectives, and proposed solutions - Commentary by a forensic examiner. Journal of Applied Research in Memory and Cognition, 2(1), 59-60.

Cooper, G.S., Meterko, V., 2019. Cognitive bias research in forensic science: A systematic review. Forensic Science International 297, 35-46.

Corredor, P., Ferrer, E., Santamaria, R., 2014. Is cognitive bias really present in analyst forecasts? The role of investor sentiment. International Business Review, 23(4), 824837.

Criminal Procedure and Investigations Act 1996. Retrieved from https://www.legislation.gov.uk/ukpga/1996/25/contents

Criminal Procedure and Investigations Act 1996 Code of Practice. Retrieved from https://www.gov.uk/government/publications/criminal-procedure-and-investigationsact-code-of-practice.

Dror, I. E., 2009. How can Francis Bacon help forensic science? The four idols of human biases. Jurimetrics, 50, 93-110.

Dror, I. E., 2013. Practical solutions to cognitive and human factor challenges in forensic science. Forensic Science Policy \& Management, 4(3-4), 105-113.

Dror, I. E., 2016. A hierarchy of expert performance. Journal of Applied Research in Memory and Cognition, 5, 121-127. 
Dror, I. E., 2017. Human expert performance in forensic decision making: Seven different sources of bias. Australian Journal of Forensic Sciences, 49(5), 541-547.

Dror, I. E., 2018. Biases in forensic experts. Science, 360(6386), 243.

Dror, I. E., Charlton, D., Péron, A. E., 2006. Contextual information renders experts vulnerable to making erroneous identifications. Forensic Science International, 156, 74-78.

Dror, I. E., Kukucka, J., Kassin, S. M., Zapf, P. A., 2018a. When expert decision making goes wrong: Consensus, bias, the role of experts, and accuracy. Journal of Applied Research in Memory and Cognition, 7, 162-163.

Dror, I. E., Langenburg, G., 2018. "Cannot decide": The fine line between appropriate inconclusive determinations versus unjustifiably deciding not to decide. Journal of Forensic Sciences, 63, 1-6.

Dror, I. E., McCormack, B. M., Epstein, J., 2015. Cognitive bias and its impact on expert witnesses and the court. The Judges' Journal, 54(4), 8-14.

Dror, I. E., McCormack, B. M., Epstein, J., 2018b. Better science for better justice: A proposal for joint experts. Science \& Justice, 58 (6), 465-66.

Dror, I. E., Morgan, R. M., Rando, C., Nakhaeizadeh, S., 2017. The bias snowball and the bias cascade effects: Two distinct biases that may impact forensic decision making Journal of Forensic Sciences, 62(3), 832-833.

Dror, I., Rosenthal, R., 2008. Meta-analytically quantifying the reliability and biasability of forensic experts. Journal of Forensic Sciences, 53(4), 900-903.

Dror, I. E., Stoel, R. D., 2014. Cognitive forensics: human cognition, contextual information, and bias. In the Encyclopaedia of Criminology and Criminal Justice (353-363), Springer.

Dror, I. E., Thompson, W. C., Meissner, C. A., Kornfield, I., Krane, D., Saks, M., Risinger, M., 2015. Context management toolbox: A linear sequential unmasking (LSU) approach for minimizing cognitive bias in forensic decision making. Journal of Forensic Sciences, 60(4), 1111-1112. 
Earwaker, H., Morgan, R. M., Harris, A. J. L., Hall, L. J., 2015. Fingermark submission decision-making within a UK fingerprint laboratory: Do experts get the marks that they need? Science \& Justice, 55(4), 239-247.

Edmond, G., Found, B., Martire, K., et al., 2016. Model forensic science. Australian Journal of Forensic Sciences, 48(5), 496-537.

van den Eeden, C. A. J., de Poot, C. J., van Koppen, P. J., 2016. Forensic expectations: Investigating a crime scene with prior information. Science \& Justice, 56(6), 475-481.

van den Eeden, C. A. J., de Poot, C. J., \& van Koppen, P. J., 2018. The forensic confirmation bias: A comparison between experts and novices. Journal of Forensic Sciences.

Evett, I. W., Williams, R. L., 1996. A Review of the sixteen points fingerprint standard in England and Wales. Journal of Forensic Identification, 46(1), 49-73.

Fingerprint Inquiry (2011).

https://www.webarchive.org.uk/wayback/archive/20170104175208/http://www.webar chive.org.uk/wayback/archive/20150428160012/http:/www.thefingerprintinquiryscotl and.org.uk/inquiry/21.html

Found, B., 2015. Deciphering the human condition: The rise of cognitive forensics. Australian Journal of Forensic Sciences, 47(4), 386-401.

Found, B., Ganas, J., 2013. The management of domain irrelevant context information in forensic handwriting examination casework. Science \& Justice, 53(2), 154-158.

French, J., Arscott, E., Morgan, R., Meakin, G., 2018. Reply to letter to the editor: Response to "A study of the perception of verbal expressions of the strength of evidence" [Letter to the editor]. Science \& Justice, 58(4), 299.

Garrett, B. L. (2011). Convicting the innocent: Where criminal prosecutions go wrong. Harvard University Press: Cambridge, MA.

de Gruijter, M., de Poot, C. J., Elffers, H., 2016. The influence of new technologies on the visual attention of CSIs performing a crime scene investigation. Journal of Forensic Sciences, 61(1), 43-51. 
Her Majesty’s Crown Prosecution Service Inspectorate, Her Majesty's Inspectorate of Constabulary, 2017. Making it fair: A joint inspection of the disclosure of unused material in volume Crown Court cases. Retrieved from https://www.justiceinspectorates.gov.uk/hmicfrs/publications/making-it-fairdisclosure-of-unused-material-in-crown-court-cases/

Howes, L. M., 2015. The communication of forensic science in the criminal justice system: A review of theory and proposed directions for research. Science \& Justice, 55(2), 145154.

House of Lords Science and Technology Select Committee. (2019). Forensic science and the criminal justice system: A blueprint for change. Available at: https://publications.parliament.uk/pa/ld201719/ldselect/ldsctech/333/33302.htm

Hussain, A., Oestreicher, J., 2018. Clinical decision-making: Heuristics and cognitive biases for the ophthalmologist. Survey of Ophthalmology, 63(1), 119-124.

Jeanguenat, A. M., Budowle, B., Dror, I. E., 2017. Strengthening forensic DNA decision making through a better understanding of the influence of cognitive bias. Science \& Justice, 57(6), 415-420.

Jeanguenat, A. M., Dror, I. E., 2018. Human factors effecting forensic decision making: Workplace stress and well-being. Journal of Forensic Sciences, 63(1), 258-261.

Kassin, S. M., Dror, I. E., Kukucka, J., 2013. The forensic confirmation bias: Problems, perspectives, and proposed solutions. Journal of Applied Research in Memory and Cognition, 2(1), 42-52.

Kelty, S. F., \& Gordon, H. (2015). No burnout at this coal-face: Managing occupational stress in forensic personnel and the implications for forensic and criminal justice agencies. Psychiatry, Psychology and Law, 22(2), 273-290.

Kelty, S. F., Julian, R., Bruenisholz, E., Wilson-Wilde, L., 2018. Dismantling the justice silos: Flowcharting the role and expertise of forensic science, forensic medicine and allied health in adult sexual assault investigations. Forensic Science International, $285,21-28$. 
Kerstholt, J., Eikelboom, A., Dijkman, T., Stoel, R., Hermsen, R., van Leuven, B., 2010. Does suggestive information cause a confirmation bias in bullet comparisons? Forensic Science International, 198, 138-142.

Kerstholt, J. H., Paashuis, R., Sjerps, M., 2007. Shoe print examinations: Effects of expectation, complexity and experience. Forensic Science International, 165(1), 30-34.

Koppl, R. 2005. How to improve forensic science. European Journal of Law and Economics, $20,255-286$.

Koppl, R., 2018. Strategic choice in linear sequential unmasking. Science \& Justice.

Krane, D. E., Ford, S., Gilder, J. R., Inman, K., Jamieson, A., Koppl, R., Kornfield, I. L., 2008. Sequential unmasking: A means of minimizing observer effects in forensic DNA interpretation [Letter to the editor]. Journal of Forensic Sciences, 53(4), 1006-1007.

Kukucka, J., Kassin, S. M., 2014. Do confessions taint perceptions of handwriting evidence? An empirical test of the forensic confirmation bias. Law and Human Behavior, 38, 256270.

Kukucka, J., Kassin, S., Zapf, P., Dror, I. E., 2017. Cognitive bias and blindness: A global survey of forensic science examiners. Journal of Applied Research in Memory and Cognition, 6 (4), 452-459.

Laporte, G., 2018. Wrongful convictions and DNA exonerations: Understanding the role of forensic science. National Institute of Justice Journal, (279), 1-16.

Mattijssen, E. J. A. T., Kerkhoff, W., Berger, C. E. H., Dror, I. E., \& Stoel, R. D. (2016). Implementing context information management in forensic casework: Minimizing contextual bias in firearms examination. Science \& Justice, 56(2), 113-122.

McCartney, C., 2018. Commentary: Disclosure in the criminal justice system. Journal of Forensic and Legal Medicine, 58, 72-73.

Montani, I., Marquis, R., Anthonioz, N. E., Champod, C., 2019. Resolving differing expert opinions. Science \& Justice, 59(1), 1-8.

Morgan, R. M., 2017a. Conceptualising forensic science and forensic reconstruction. Part I: A conceptual model. Science \& Justice, 57(6), 455-459. 
Morgan, R. M., 2017b. Conceptualising forensic science and forensic reconstruction. Part II: The critical interaction between research, policy/law and practice. Science \& Justice, $57(6), 460-467$.

Morgan, R. M. 2018. Forensic science needs the 'hedgehog' and the 'fox'. Forensic Science International, 292, e10-e12.

Morgan, R. M., Nakhaeizadeh, S., Earwaker, H., Rando, C., Harris, A. J. L., Dror, I. E., 2018. Interpretation of evidence: Cognitive decision making under uncertainty (at every step of the forensic science process); in Wortley, R., Sidebottom, A., Laycock, G., Tilley, N. (Eds.), Handbook of Crime Science. Routledge, Abingdon, pp. 408-420.

Murrie, D. C., Boccaccini, M. T., Guarnera, L. A., \& Rufino, K. A. (2013). Are forensic experts biased by the side that retained them? Psychological Science, 24(10), 1889-1897.

Nakhaeizadeh, S., Dror, I. E., Morgan, R. M., 2014. Cognitive bias in forensic anthropology: Visual assessment of skeletal remains is susceptible to confirmation bias. Science \& Justice, 54(3), 208-214.

Nakhaeizadeh, S., Morgan, R. M., Rando, C., Dror, I. E., 2017. Cascading bias of initial exposure to information at the crime scene to the subsequent evaluation of skeletal remains. Journal of Forensic Sciences, 1-9.

National Commision on Forensic Science., 2015. Ensuring that forensic analysis is based upon task-relevant information. Retrieved from https://www.justice.gov/archives/ncfs/file/818196/download

National Research Council., 2009. Strengthening forensic science in the United States: A path forward. Washington DC: The National Academies Press.

Office of the Inspector General., 2006. A review of the FBI's handling of the Brandon Mayfield case. Retrieved from https://oig.justice.gov/special/s0601/final.pdf

Oliver, W. R., 2018. Comment on Kukucka, Kassin, Zapf, and Dror (2017), "Cognitive bias and blindness: A global survey of forensic science examiners." Journal of Applied Research in Memory and Cognition, 7(1), 161. 
Osborne, N. K. P., Taylor, M. C., 2018. Contextual information management: An example of independent-checking in the review of laboratory-based bloodstain pattern analysis. Science \& Justice, 58(3), 226-231.

Osborne, N. K. P., Taylor, M. C., Healey, M., Zajac, R., 2016. Bloodstain pattern classification: Accuracy, effect of contextual information and the role of analyst characteristics. Science \& Justice, 56(2), 123-128.

Osborne, N. K. P., Woods, S., Kieser, J., Zajac, R., 2014. Does contextual information bias bitemark comparisons? Science \& Justice, 54(4), 267-273.

Page, M., Taylor, J., Blenkin, M., 2012. Context effects and observer bias-implications for forensic odontology. Journal of Forensic Sciences, 57(1), 108-112.

Pronin, E., Kugler, M., 2007. Valuing thoughts, ignoring behavior: The introspection illusion as a source of the bias blind spot. Journal of Experimental Social Psychology, 43(4), $565-578$.

Quirk, H., 2006. The significance of culture in criminal procedure reform: Why the revised disclosure scheme cannot work. The International Journal of Evidence \& Proof, 10, $42-59$.

$R v$ Smith [2011] EWCA Crim 1296. (n.d.).

Raymond, T., Julian, R., 2015. Forensic intelligence in policing: Organisational and cultural change. Australian Journal of Forensic Sciences, 47(4), 371-385.

Risinger, D.M., Saks, M.J., Thompson, W.C., Rosenthal, R., 2002. The Daubert Kumho implications of observer effects in forensic science: Hidden problems of expectation and suggestion. California Law Review, 90, 1-56.

Roux, C., Crispino, F., Ribaux, O., 2012. From forensics to forensic science. Current Issues in Criminal Justice, 24(1), 7-24.

Saks, M. J., Koehler, J., 2005. The coming paradigm shift in forensic identification science. Science, 309(5736), 892-895. 
Saks, M. J., Risinger, D. M., Rosenthal, R., Thompson, W. C., 2003. Context effects in forensic science: A review and application of the science of science to crime laboratory practice in the United States. Science \& Justice, 43(2), 77-90.

The Santa Clara County District Attorney's Crime Laboratory. 2018. Retrieved from: https://www.sccgov.org/sites/da/prosecution/DistrictAttorneyDepartments/Pages/Cri $\underline{\text { me\%20Laboratory.aspx }}$

Smalarz, L., Madon, S., Yang, Y., Guyll, M., Buck, S., 2016. The perfect match: Do criminal stereotypes bias forensic evidence analysis? Law and Human Behavior, 40(4), 420429.

Smit, N. M., Morgan, R. M., Lagnado, D. A., 2018. A systematic analysis of misleading evidence in unsafe rulings in England and Wales. Science \& Justice, 58(2), 128-137.

Stevenage, S. V., Bennett, A., 2017. A biased opinion: Demonstration of cognitive bias on a fingerprint matching task through knowledge of DNA test results. Forensic Science International, 276, 93-106.

Taylor, M. C., Laber, T. L., Kish, P. E., Owens, G., Osborne, N. K. P., 2016a. The reliability of pattern classification in bloodstain pattern analysis, Part 1: Bloodstain patterns on rigid non-absorbent surfaces. Journal of Forensic Sciences, 61(4), 922-927.

Taylor, M. C., Laber, T. L., Kish, P. E., Owens, G., Osborne, N. K. P., 2016b. The reliability of pattern classification in bloodstain pattern analysis-PART 2: Bloodstain patterns on fabric surfaces. Journal of Forensic Sciences, 61(6), 1461-1466.

The Forensic Science Regulator., 2015. Cognitive bias effects relevant to forensic science examinations. Retrieved from https://www.gov.uk/government/publications/cognitive-bias-effects-relevant-toforensic-science-examinations

Thompson, W. C., Ford, S., Gilder, J. R., Inman, K., Jamieson, A., Koppl, R., Kornfield, I. L., 2011. Commentary on: Thornton JI. Letter to the editor-a rejection of "working blind" as a cure for contextual bias [Letter to the editor]. Journal of Forensic Sciences, 56(2), $562-563$. 
Thornton, J. I., 2010. A rejection of "working blind" as a cure for contextual bias [Letter to the editor]. Journal of Forensic Sciences, 55(6), 1663.

Zapf, P., Kukucka, J., Kassin, S., Dror, I. E., 2018. Cognitive bias in forensic mental health assessment: Evaluator beliefs about its nature and scope. Psychology, Public Policy and Law, 24 (1), 1-10. 